\title{
Postharvest conservation of minimally processed cassava roots subjected to different packaging systems
}

\section{Conservação pós-colheita de raízes de mandioca minimamente processadas submetidas a diferentes sistemas de embalagem}

\author{
Maria Madalena RINALDI ${ }^{1}$; Eduardo Alano VIEIRA²; Josefino de Freitas FIALHO ${ }^{3}$ \\ ${ }^{1}$ Autor para correspondência. Pesquisadora Classe A, Doutora em Ciência e Tecnologia Pós-colheita, Embrapa Cerrados \\ (CPAC) Rodovia BR-020, km 18 Caixa Postal: 08223 CEP: 73310-970 - Planaltina - DF. madalena.rinaldi@embrapa.br \\ ${ }_{2}$ Pesquisador Classe A, Doutor em Recursos Genéticos e Melhoramento Vegetal, Embrapa Cerrados (CPAC) Planaltina, DF. \\ eduardo.alano@embrapa.br \\ ${ }^{3}$ Pesquisador Classe B, Mestre em Fitotecnia, Embrapa Cerrados (CPAC) Planaltina, DF. josefino.fialho@embrapa.br
}

Recebido em: 05-12-2018; Aceito em: 25-02-2019

\begin{abstract}
Cassava (Manihot esculenta Crantz) is one of the main energy sources in human food, being largely consumed and produced in Brazil. However, it is not easy to prepare and has a high deterioration degree after harvest. As an alternative, producers and agribusinesses are extensively using vacuum packaging for the storage of minimally processed cassava roots. This study evaluates the postharvest conservation of minimally processed cassava roots packed in $130 \mu \mathrm{m}, 200 \mu \mathrm{m}$, and $300 \mu \mathrm{m}$ LDPE packages with and without vacuum, stored at $3{ }^{\circ} \mathrm{C}$ and $90 \%$ relative humidity. Samples were evaluated every seven days for a period of 28 days for $\mathrm{pH}$, titratable acidity, soluble solids, SS/TA ratio, texture, fresh weight loss, moisture, dry matter, cooking time, color $\left(L^{*}, a^{*}, b^{*}\right.$, increase in browning, chroma, and hue angle), and microbiology (counting mesophilic aerobes, psychrotrophic aerobes, molds and yeasts, total and thermotolerant coliforms). Minimally processed cassava roots packed in LDPE packages with higher thickness $(200 \mu \mathrm{m}$ and $300 \mu \mathrm{m})$ show greater stability in physicochemical and microbiological components. For packages $200 \mu \mathrm{m}$ vacuum LDPE and $300 \mu \mathrm{m}$ LDPE in the two atmosphere conditions, stored at $3 \stackrel{\circ}{ } \mathrm{C}$ and $90 \%$ relative humidity, the shelf life of minimally processed cassava roots was 14 days. The recommended storage period for the remaining treatments is seven days.
\end{abstract}

Additional keywords: Manihot esculenta Crantz; minimal processing; storage; vacuum packaging; conservation.

\section{Resumo}

A mandioca (Manihot esculenta Crantz) é uma das principais fontes mundiais de energia na alimentação humana, grandemente consumida e produzida no Brasil; entretanto, não apresenta facilidade no preparo e tem um alto grau de deterioração após a colheita. Como alternativa, o processo de embalagem a vácuo para o acondicionamento de raízes de mandioca minimamente processadas tem sido utilizado consideravelmente pelos produtores e pelas agroindústrias. Assim, o objetivo deste trabalho foi avaliar a conservação pós-colheita de raízes de mandioca de mesa minimamente processadas e acondicionadas em embalagens PEBD $130 \mu \mathrm{m}, 200 \mu \mathrm{m}$ e $300 \mu \mathrm{m}$, com e sem vácuo, armazenadas na temperatura de $3 \stackrel{\circ}{\circ} \mathrm{C} \mathrm{e} 90 \%$ de umidade relativa. As amostras foram avaliadas a cada sete dias, por um período de 28 dias, quanto ao $\mathrm{pH}$, acidez titulável, sólidos solúveis, Ratio, textura, perda de massa fresca, umidade, matéria seca, tempo de cocção, cor $\left(\mathrm{L}^{*}, \mathrm{a}^{*}, \mathrm{~b}^{*}\right.$, incremento no escurecimento, croma e ângulo hue) e microbiologia para a contagem de aeróbios mesófilos, aeróbios psicrotróficos, bolores e leveduras, coliformes totais e termotolerantes. Raízes de mandioca minimamente processadas acondicionadas nas embalagens de PEBD com maior espessura (200 $\mu \mathrm{m}$ e $300 \mu \mathrm{m})$, apresentam maior estabilidade nos componentes físicos-químicos e microbiológicos. Na embalagem PEBD $200 \mu \mathrm{m}$ com vácuo e PEBD $300 \mu \mathrm{m}$ nas duas condições de atmosfera e armazenamento na temperatura de $3 \stackrel{\circ}{\circ}$ e $90 \%$ de umidade relativa, a vida útil das raízes de mandioca minimamente processada foi de 14 dias. Nos demais tratamentos, o período de armazenamento recomendado foi de sete dias.

Palavras-chave adicionais: Manihot esculenta Crantz; processamento mínimo; armazenamento; acondicionamento a vácuo; conservação.

\section{Introduction}

Brazil is the fourth largest producer of cassava in the world, after Nigeria, Thailand, and Indonesia, whose climatic conditions are the main factors regu- lating production (Moreto et al., 2018). This crop is fundamental for the Brazilian socioeconomic scenario, with cultivation in both small and large farms. Moreover, cassava is versatile, with potential to be planted in all regions of Brazil (Santiago et al., 2018). 
In the green belt of large and medium-sized Brazilian cities, cassava is mainly grown for culinary consumption (precooked, cooked, fried, chips, cassava stick, among others) of its reserve roots (Vieira et al., 2018). The crop is one of the preferred by the producers because of its high profitability and adaptation to crop rotation and/or succession with other vegetables.

Physiological deterioration of roots represents one of the great difficulties of the cassava market. The deterioration process begins in the first 48 hours after harvest, limiting its storage and hindering commercialization (Ramos et al., 2013).

Minimally processed cassava is an alternative to add value to the raw material and to meet the needs of consumers looking for easy-to-prepare products (Vieites et al., 2012). Farmers, wholesalers, and supermarkets are increasingly using processed cassava, since today's consumers consider the practicality of minimally processed products over their prices (Andrade et al., 2016).

Among the different techniques and methods of food preservation, the study of packaging has stood out due to the need to preserve physicochemical and sensory characteristics. In addition to the package definition, the use of vacuum can result in a longer shelf life due to reduced microorganism development, oxidation, and discoloration (Ricciardi, 2008). According to Cenci (2011), the use of vacuum in packaging promotes the suppression of oxygen, which tends to increase the shelf life of the food because it slows respiration, maturation, aging, moisture loss, texture change, enzymatic browning, and the development of microorganisms. The use of vacuum packaging is efficient in the preservation of meat, pasta, eggs, and grains (Lima et al., 2014). When evaluating the quality of minimally processed cassava subjected to gamma radiation, Vieites et al. (2012) packed minimally processed cassava roots (IAC-576-70) in two different situations. The first situation consisted of expanded polystyrene packages coated with low density polyethylene (LDPE) plastic film subjected to different irradiation rates. The second situation included minimally processed roots packed only in nylon + polyethylene packaging with vacuum application, stored under refrigeration at $5{ }^{\circ} \mathrm{C}$ for 12 days. The authors concluded that the vacuum treatment associated with refrigeration allowed a slight superiority compared to the other treatments.

Despite being widely used by producers and agribusinesses, there is insufficient scientific information on physicochemical and microbiological characteristics of minimally processed cassava roots packaged and marketed in vacuum packages of different thicknesses, as well as on the shelf life of this product. Thus, this study evaluates the postharvest conservation of minimally processed cassava roots packed in $130 \mu \mathrm{m}, 200 \mu \mathrm{m}$, and $300 \mu \mathrm{m}$ PEBD packages with and without vacuum, stored at $3{ }^{\circ} \mathrm{C}$ and $90 \%$ relative humidity.

\section{Materials and methods}

The work was developed in the Laboratory of Food Science and Technology of Embrapa Cerrados, located in Planaltina - DF. Cassava cultivar IAC 576-70 was used, popularly known in the Cerrado region as "Japonesinha", with cream root pulp.

Twelve months after planting, the roots were harvested, transported to the laboratory, washed in running water, and cooled in a cold room (10 $\pm 1 \stackrel{\circ}{\circ} \mathrm{C}$ and $90 \%$ relative humidity) for 12 hours. Minimal processing consisted of manually peeling the roots and discarding the tips; washing under running water; and cutting the median part of roots into cylinders $(10 \mathrm{~cm}$ long). Moreover, the following procedures were performed: immersion (10 minutes) in sanitizing solution of sodium hypochlorite with $150 \mathrm{mg} \cdot \mathrm{L}^{-1}$ active chlorine; rinsing (5 minutes) in $5 \mathrm{mg} \cdot \mathrm{L}^{-1}$ solution of the same sanitizer; and root draining for five minutes in a stainless steel drainer similar to those used in semi-industrial restaurants. The temperature of the running, sanitizing, and rinsing water was maintained at $5 \pm 2{ }^{\circ} \mathrm{C}$. The processing area was previously sanitized, as well as all utensils kept inside. Room temperature was maintained at $15 \pm 3{ }^{\circ} \mathrm{C}$, and individual protective equipment (IPE) was used.

Minimally processed cassava roots were packed in LDPE plastic bags with $130 \mu \mathrm{m}, 200 \mu \mathrm{m}$, and $300 \mu \mathrm{m}$. All studied packages were closed with and without vacuum, consisting of the following treatments: $130 \mu \mathrm{m}$ nonvacuum LDPE, $130 \mu \mathrm{m}$ vacuum LDPE, $200 \mu \mathrm{m}$ nonvacuum LDPE, $200 \mu \mathrm{m}$ vacuum LDPE, $300 \mu \mathrm{m}$ nonvacuum LDPE, $300 \mu \mathrm{m}$ vacuum LDPE. All packages containing minimally processed cassava roots were stored in a cold room at $3^{\circ} \mathrm{C}$ and $90 \%$ relative humidity.

After minimal processing and at $7,14,21$, and 28 days of storage, the product was analyzed for $\mathrm{pH}$, titratable acidity, soluble solids, SS/TA ratio, moisture, and dry matter content according to Carvalho et al. (1990). Texture analysis was based on the perforation resistance test (normal test) using the Brookfield texture Analyzer, model CT3 4500. The following configuration was set: trigger (strength) at $10 \mathrm{~g}$, deformation at $10 \mathrm{~mm}$, and speed at $10 \mathrm{~mm} / \mathrm{s}$, using TA 17 tips with a $30 \mathrm{~mm}$ D cone, $40^{\circ}$, and TA $15 / 1000$ tips with a $30 \mathrm{~mm}$ $\mathrm{D}$ cone, $45^{\circ}$. The results were expressed in Newton. Fresh weight loss during storage was determined by the difference between the initial weight and the weight at the time of evaluation. Cooking time was evaluated according to Butarelo et al. (2004). Color ( $\left.\mathrm{L}^{*}, \mathrm{a}^{*}, \mathrm{~b}^{*}\right)$ was determined using a MiniScan ${ }^{\circledR}$ EZ spectrophotometer (brand HunterLab). $L^{*}$ defines luminosity $\left(L^{*}=0\right.$ black and $L^{*}=100$ white); $a^{*}$ and $b^{*}$ define chromaticity $\left(+a^{*}\right.$ red and $-a^{*}$ green; $+b^{*}$ yellow and $-b^{*}$ blue). The values of $L^{*}$, $a^{*}$, and $b^{*}$ made it possible to calculate the chroma (color saturation or intensity: 0 - impure color; 60 - pure color) and the hue angle $\left(0^{\circ} \mathrm{red}, 90^{\circ}\right.$ yellow, $180^{\circ}$ green, $270^{\circ}$ blue, and $360^{\circ}$ black). As recommended by Hunterlab (2008), the following formulas were used: 
chroma $\left[\left(a^{2}+b^{2}\right)^{1 / 2}\right]$ and hue angle [tangent arc $\left.(b / a)\right]$. Microbiological analysis was performed according to Silva et al. (2010) for the counting of mesophilic aerobes, psychrotrophic aerobes, molds and yeasts, total and thermotolerant coliforms.

\section{Experimental design and statistical analysis}

The experimental design was completely randomized with three replicates for each analysis. Each replicate consisted of approximately $500 \mathrm{~g}$ of minimally processed cassava roots. For color and texture analysis, three readings were performed in each $10-\mathrm{cm}$-long cylinder of minimally processed cassava roots. The data were submitted to analysis of variance, and means were compared by the Tukey test at $1 \%$ probability, using the Assistat software (Silva, 2015).

\section{Results and discussion}

\section{pH, titratable acidity, and soluble solids}

The $\mathrm{pH}$ values did not vary significantly during storage, ranging between 5.96 and 6.32, with an initial value of 6.04 (Table 1). Low oscillation in $\mathrm{pH}$ values during storage may be related to the association between storage temperature and adequate packaging, resulting in efficient respiration control (Freire et al., 2014).

Table 1 - Mean values of $\mathrm{pH}$, titratable acidity and soluble solids in minimally processed cassava roots submitted to different treatments.

\begin{tabular}{|c|c|c|c|c|c|}
\hline \multirow{2}{*}{ Packages } & \multicolumn{5}{|c|}{ Days of storage } \\
\hline & 0 & 7 & 14 & 21 & 28 \\
\hline $\begin{array}{l}\text { LDPE } 130 \mu \mathrm{m} \text { without vacuum } \\
\text { LDPE } 130 \mu \mathrm{m} \text { with vacuum } \\
\text { LDPE } 200 \mu \mathrm{m} \text { without vacuum } \\
\text { LDPE } 200 \mu \mathrm{m} \text { with vacuum } \\
\text { LDPE } 300 \mu \mathrm{m} \text { without vacuum } \\
\text { LDPE } 300 \mu \mathrm{m} \text { with vacuum }\end{array}$ & $\begin{array}{l}6.04 \mathrm{aA} \\
6.04 \mathrm{aA} \\
6.04 \mathrm{aA} \\
6.04 \mathrm{aA} \\
6.04 \mathrm{aA} \\
6.04 \mathrm{aA}\end{array}$ & $\begin{array}{l}6.16 \mathrm{aA} \\
6.11 \mathrm{aA} \\
6.16 \mathrm{aA} \\
6.18 \mathrm{aA} \\
6.12 \mathrm{aA} \\
6.16 \mathrm{aA}\end{array}$ & $\begin{array}{c}\mathrm{pH} \\
6.20 \mathrm{aA} \\
6.16 \mathrm{aA} \\
5.96 \mathrm{aA} \\
6.24 \mathrm{aA} \\
6.00 \mathrm{aA} \\
6.14 \mathrm{aA} \\
\end{array}$ & $\begin{array}{l}6.21 \mathrm{aA} \\
6.16 \mathrm{aA} \\
6.31 \mathrm{aA} \\
6.31 \mathrm{aA} \\
6.20 \mathrm{aA} \\
6.32 \mathrm{aA} \\
\end{array}$ & $\begin{array}{l}6.18 \mathrm{aA} \\
6.03 \mathrm{aA} \\
6.08 \mathrm{aA} \\
6.30 \mathrm{aA} \\
6.11 \mathrm{aA} \\
6.27 \mathrm{aA}\end{array}$ \\
\hline LDPE $300 \mu \mathrm{m}$ with vacuum & \multicolumn{5}{|c|}{ Titratable acidity ( $\mathrm{g}$ anhydrous citric acid/100 g) } \\
\hline LDPE $130 \mu \mathrm{m}$ without vacuum & $0.11 \mathrm{aB}$ & $0.06 \mathrm{cC}$ & $0.11 \mathrm{aB}$ & $0.13 \mathrm{aA}$ & $0.04 \mathrm{cD}$ \\
\hline LDPE $130 \mu \mathrm{m}$ with vacuum & $0.11 \mathrm{aA}$ & $0.07 \mathrm{bcB}$ & $0.08 \mathrm{bB}$ & $0.12 \mathrm{aA}$ & $0.11 \mathrm{aA}$ \\
\hline LDPE $200 \mu \mathrm{m}$ without vacuum & $0.11 \mathrm{aA}$ & $0.08 \mathrm{bcB}$ & $0.09 \mathrm{abA}$ & $0.09 \mathrm{bA}$ & $0.11 \mathrm{aA}$ \\
\hline LDPE $200 \mu \mathrm{m}$ with vacuum & $0.11 \mathrm{aA}$ & $0.10 \mathrm{aA}$ & $0.08 \mathrm{bB}$ & $0.12 \mathrm{aA}$ & $0.09 \mathrm{bB}$ \\
\hline LDPE $300 \mu \mathrm{m}$ without vacuum & $0.11 \mathrm{aA}$ & $0.08 \mathrm{bcB}$ & $0.09 \mathrm{abB}$ & $0.11 \mathrm{abA}$ & $0.11 \mathrm{aA}$ \\
\hline \multirow[t]{2}{*}{ LDPE $300 \mu \mathrm{m}$ with vacuum } & $0.11 \mathrm{aA}$ & $0.07 \mathrm{bcC}$ & $0.09 \mathrm{abB}$ & $0.11 \mathrm{abA}$ & $0.09 \mathrm{bB}$ \\
\hline & \multicolumn{5}{|c|}{ Soluble solids (ํㅏix) } \\
\hline LDPE $130 \mu \mathrm{m}$ without vacuum & $7.00 \mathrm{aA}$ & $7.87 \mathrm{aA}$ & $8.10 \mathrm{aA}$ & $7.40 \mathrm{aA}$ & $7.27 \mathrm{aA}$ \\
\hline LDPE $130 \mu \mathrm{m}$ with vacuum & $7.00 \mathrm{aA}$ & $7.60 \mathrm{aA}$ & $7.13 \mathrm{aA}$ & $8.50 \mathrm{aA}$ & $9.57 \mathrm{aA}$ \\
\hline LDPE $200 \mu \mathrm{m}$ without vacuum & $7.00 \mathrm{aA}$ & $7.63 \mathrm{aA}$ & $7.20 \mathrm{aA}$ & $7.03 \mathrm{aA}$ & $7.83 \mathrm{aA}$ \\
\hline LDPE $200 \mu \mathrm{m}$ with vacuum & $7.00 \mathrm{aA}$ & $7.47 \mathrm{aA}$ & $7.77 \mathrm{aA}$ & $7.07 \mathrm{aA}$ & $7.07 \mathrm{aA}$ \\
\hline LDPE $300 \mu \mathrm{m}$ without vacuum & $7.00 \mathrm{aA}$ & $8.63 \mathrm{aA}$ & 7.97 aA & $7.93 \mathrm{aA}$ & $8.63 \mathrm{aA}$ \\
\hline LDPE $300 \mu \mathrm{m}$ with vacuum & $7.00 \mathrm{aA}$ & $7.17 \mathrm{aA}$ & $7.83 \mathrm{aA}$ & $7.33 \mathrm{aA}$ & $6.87 \mathrm{aA}$ \\
\hline
\end{tabular}

Means followed by different lowercase and uppercase letters in the same column and row, respectively, differ from each other at $1 \%$ probability by the Tukey test.

There is a relationship between increased $\mathrm{pH}$ and decreased titratable acidity in stored products due to the consumption of organic acids as substrates in the respiratory process (Chitarra \& Chitarra, 2005). Rinaldi et al. (2015a) observed a significant increase in $\mathrm{pH}$ values of minimally processed cassava roots conditioned with and without vacuum and stored under refrigeration and freezing (without vacuum) for cultivars IAC 576-70, BRS 400, and BRS 399, differing from that observed in this study. The $\mathrm{pH}$ value determines the enzymatic activity, the deterioration degree, the texture variation, the degree of maturation of fruits and vegetables, and the choice of the most appropriate packaging and storage conditions (Chitarra \& Chitarra, 2005). Foods with low acidity $(\mathrm{pH}>4.5)$ are more susceptible to microbial, pathogenic, or deteriorating de- velopment (Franco \& Landgraf, 2005). In this context, the $\mathrm{pH}$ observed in all treatments is favorable to the development of these microorganisms, which may cause a decrease in root storage time (Teixeira et al., 2017). Thus, the storage condition and temperature must be well defined for maintaining postharvest quality of minimally processed cassava roots.

Titratable acidity values varied significantly throughout the storage, with fluctuation in practically all treatments. The initial value was $0.11 \mathrm{~g}$ anhydrous citric acid per $100 \mathrm{~g}$, and the lowest value (0.04) was observed at 28 days of storage for roots packed in $130 \mu \mathrm{m}$ nonvacuum LDPE (Table 1). With the exception of the $200 \mu \mathrm{m}$ vacuum LDPE package, all treatments decreased titratable acidity values during the first seven days of storage. This indicates that the main 
metabolic changes occurred at this stage for roots subjected to these treatments. Titratable acidity values tend to decrease during storage of refrigerated products due to the use of acids in the respiratory process (Rinaldi et al., 2015b). In the study by Vieites et al. (2012), minimally processed cassava only vacuumpackaged had higher values of titratable acidity when compared to the other treatments subjected to different irradiation rates, which did not occur in the present study, in which titratable acidity values oscillated and decreased during storage.

Soluble solids content did not vary significantly during storage probably due to the low metabolism of roots, the packages used, and mainly the low storage temperature $\left(3^{\circ} \mathrm{C}\right)$ (Table 1$)$. Although not statistically significant, the highest soluble solids content was obtained for minimally processed cassava roots kept in the $130 \mu \mathrm{m}$ vacuum LDPE package, at 28 days of storage. The lowest value was also obtained at 28 days for roots packed in the $300 \mu \mathrm{m}$ vacuum LDPE package.

Throughout the storage period, the soluble solids content ranged from $6.87^{\circ}$ Brix to $9.57^{\circ}$ Brix, with an initial value of $7.00^{\circ} \mathrm{Brix}$ (Table 1). The variation in soluble solids contents during storage is influenced by intrinsic characteristics of the sample, by metabolic reactions that may occur during the storage period, using sugar as a substrate, and by microbial activity in the product kept under refrigeration (Rinaldi et al., 2015a). Thus, we can affirm that the processing, packaging, and storage conditions were adequate for the maintenance of this variable. Soluble solids represent an important variable in postharvest evaluation, since they allow to infer about the flavor of the vegetable (Castricini et al., 2014). This characteristic can influence the final quality of cassava products such as cakes, ice cream, biscuits, purees, and others. In addition, higher levels of soluble solids tend to provide more sweetness and better taste, meeting consumers' preference (Teixeira et al., 2017).

\section{SS/TA ratio, texture, and fresh weight loss}

The SS/TA ratio values correspond to the ratio between soluble solids and titratable acidity, basically defining root flavor and maturity stage. In general, with the exception of products subjected to the $130 \mu \mathrm{m}$ nonvacuum LDPE package and the $200 \mu \mathrm{m}$ vacuum LDPE package, the highest SS/TA ratio was observed at seven days of storage (Table 2). The packages also varied significantly for this variable from 7 to 28 days of storage. The SS/TA ratio values ranged between 58.39

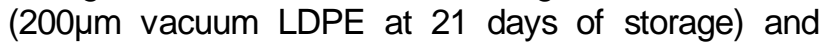

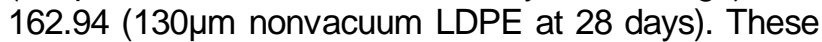
values tend to increase during plant maturation due to increased sugars and decreased acids (Cavalini et al., 2006). In the present study, the values of this variable oscillated as a function of the values of soluble solids and titratable acidity (Table 1). The soluble solids/titratable acidity ratio is generally a good indicator of flavor, in which the balance between these two components is a good outcome (Fernandes et al., 2010).

Table 2 - Mean values of ratio, texture and loss of fresh mass in minimally processed cassava roots submitted to different treatments.

\begin{tabular}{|c|c|c|c|c|c|}
\hline \multirow{2}{*}{ Packages } & \multicolumn{5}{|c|}{ Days of storage } \\
\hline & 0 & 7 & 14 & 21 & 28 \\
\hline & \multicolumn{5}{|c|}{ Ratio } \\
\hline LDPE $130 \mu \mathrm{m}$ without vacuum & $64.12 \mathrm{aD}$ & $133.50 \mathrm{aB}$ & $76.18 \mathrm{cC}$ & $58.73 \mathrm{cD}$ & $162.94 \mathrm{aA}$ \\
\hline LDPE $130 \mu \mathrm{m}$ with vacuum & $64.12 \mathrm{aC}$ & $111.70 \mathrm{bA}$ & $92.78 \mathrm{aB}$ & $65.26 \mathrm{bC}$ & $94.31 \mathrm{bB}$ \\
\hline LDPE $200 \mu \mathrm{m}$ without vacuum & $64.12 \mathrm{aD}$ & $102.16 \mathrm{cA}$ & $80.87 \mathrm{bcB}$ & $78.01 \mathrm{aB}$ & $71.52 \mathrm{dC}$ \\
\hline LDPE $200 \mu \mathrm{m}$ with vacuum & $64.12 \mathrm{aC}$ & $79.85 \mathrm{~dB}$ & $92.61 \mathrm{abA}$ & $58.39 \mathrm{cC}$ & $82.22 \mathrm{cB}$ \\
\hline LDPE $300 \mu \mathrm{m}$ without vacuum & $64.12 \mathrm{aD}$ & $113.59 \mathrm{bA}$ & $87.80 \mathrm{bB}$ & $72.30 \mathrm{abC}$ & $76.33 \mathrm{dC}$ \\
\hline \multirow[t]{2}{*}{ LDPE $300 \mu \mathrm{m}$ with vacuum } & $64.12 \mathrm{aC}$ & $99.83 \mathrm{cA}$ & $85.52 \mathrm{bB}$ & $68.45 \mathrm{bC}$ & $82.02 \mathrm{cB}$ \\
\hline & \multicolumn{5}{|c|}{ Texture $(\mathrm{N})$} \\
\hline LDPE $130 \mu \mathrm{m}$ without vacuum & $30.0 \mathrm{aA}$ & $24.23 \mathrm{aA}$ & $24.67 \mathrm{aA}$ & $22.03 \mathrm{aA}$ & $21.96 \mathrm{aA}$ \\
\hline LDPE $130 \mu \mathrm{m}$ with vacuum & $30.0 \mathrm{aA}$ & $25.80 \mathrm{aA}$ & $24.97 \mathrm{aA}$ & $22.73 \mathrm{aA}$ & $20.20 \mathrm{aA}$ \\
\hline LDPE $200 \mu \mathrm{m}$ without vacuum & $30.0 \mathrm{aA}$ & $21.80 \mathrm{aA}$ & $24.50 \mathrm{aA}$ & $26.10 \mathrm{aA}$ & $23.27 \mathrm{aA}$ \\
\hline LDPE $200 \mu \mathrm{m}$ with vacuum & $30.0 \mathrm{aA}$ & $23.03 \mathrm{aA}$ & $25.57 \mathrm{aA}$ & $23.77 \mathrm{aA}$ & $23.53 \mathrm{aA}$ \\
\hline LDPE $300 \mu \mathrm{m}$ without vacuum & $30.0 \mathrm{aA}$ & $22.73 \mathrm{aA}$ & $24.77 \mathrm{aA}$ & $24.50 \mathrm{aA}$ & $20.20 \mathrm{aA}$ \\
\hline \multirow[t]{2}{*}{ LDPE $300 \mu \mathrm{m}$ with vacuum } & $30.0 \mathrm{aA}$ & $22.07 \mathrm{aA}$ & $24.23 \mathrm{aA}$ & $25.03 \mathrm{aA}$ & $24.93 \mathrm{aA}$ \\
\hline & \multicolumn{5}{|c|}{ Loss of fresh mass (\%) } \\
\hline LDPE $130 \mu \mathrm{m}$ without vacuum & $0.00 \mathrm{aA}$ & $0.00 \mathrm{aA}$ & $0.02 \mathrm{aA}$ & $0.02 \mathrm{aA}$ & $0.07 \mathrm{aA}$ \\
\hline LDPE $130 \mu \mathrm{m}$ with vacuum & $0.00 \mathrm{aA}$ & $0.03 \mathrm{aA}$ & $0.09 \mathrm{aA}$ & $0.11 \mathrm{aA}$ & $0.12 \mathrm{aA}$ \\
\hline LDPE $200 \mu \mathrm{m}$ without vacuum & $0.00 \mathrm{aA}$ & $0.00 \mathrm{aA}$ & $0.01 \mathrm{aA}$ & $0.07 \mathrm{aA}$ & $0.08 \mathrm{aA}$ \\
\hline LDPE $200 \mu \mathrm{m}$ with vacuum & $0.00 \mathrm{aA}$ & $0.01 \mathrm{aA}$ & $0.01 \mathrm{aA}$ & $0.02 \mathrm{aA}$ & $0.09 \mathrm{aA}$ \\
\hline LDPE $300 \mu \mathrm{m}$ without vacuum & $0.00 \mathrm{aA}$ & $0.00 \mathrm{aA}$ & $0.01 \mathrm{aA}$ & $0.03 \mathrm{aA}$ & $0.06 \mathrm{aA}$ \\
\hline LDPE $300 \mu \mathrm{m}$ with vacuum & $0.00 \mathrm{aB}$ & $0.03 \mathrm{aAB}$ & $0.01 \mathrm{aAB}$ & $0.01 \mathrm{aAB}$ & $0.10 \mathrm{aA}$ \\
\hline
\end{tabular}

Means followed by different lowercase and uppercase letters in the same column and row, respectively, differ from each other at $1 \%$ probability by the Tukey test. 
Texture did not differ significantly between packages and between storage periods; as expected, it had only a gradual but not expressive decrease. Although there was no significant difference in texture data during storage, all treatments had a more pronounced reduction during the first seven days of storage (Table 2). Rinaldi et al. (2017b) also did not observe a significant difference in the texture of cassava roots of the same cultivar. The roots were immersed in water with different concentrations of citric acid after minimal processing, with texture values ranging between $39.66 \mathrm{~N}$ and $16.71 \mathrm{~N}$. The storage temperature was set at $30^{\circ} \mathrm{C}$ for 35 days. In turn, Teixeira et al. (2017) obtained the average texture value of $22.66 \mathrm{~N}$ after harvesting cassava roots of the variety IAC 576-70, which is a lower value than that obtained for the same variety in the present study. The textural properties of minimally processed foods indicate their quality, in which packaging is fundamental to maintain the conservation of these products (Fernandes et al., 2016). In the present study, there was no significant effect of packaging on the texture of the product.

There was no significant increase in fresh weight loss in all treatments during storage, with a loss of $0 \%$ to $0.12 \%$, which did not influence product quality (Table 2). Freire et al. (2014) also did not observe a significant increase of fresh weight loss in minimally processed cassava roots stored at $5 \pm 20{ }^{\circ} \mathrm{C}$ for 11 days. According to these authors, low fresh weight loss in minimally processed cassava roots may be due to lignification, which can act as a natural barrier to water loss, resulting in less susceptibility to dehydration. Weight loss occurs mainly due to the loss of moisture by transpiration (Freitas et al., 2017).

\section{Color}

Table 3 shows the color values, expressed in $L^{*}, a^{*}, b^{*}$. Samples packaged in $200 \mu \mathrm{m}$ vacuum LDPE and $300 \mu \mathrm{m}$ nonvacuum LDPE showed higher stability in $L^{*}$ values, with no significant variation during the 28 days of storage. The lower the $L^{*}$ values, the darker the samples. The highest $L^{*}$ value (89.06) was obtained at the beginning of storage, and the lowest value (66.48) occurred in the samples of minimally processed roots conditioned in the $200 \mu \mathrm{m}$ nonvacuum LDPE package, at 28 days of storage.

Table 3 - Mean values of $L{ }^{*}$, $a$ * and $b$ * in minimally processed cassava roots submitted to different treatments.

\begin{tabular}{|c|c|c|c|c|c|}
\hline \multirow{2}{*}{ Packages } & \multicolumn{5}{|c|}{ Days of storage } \\
\hline & 0 & 7 & 14 & 21 & 28 \\
\hline & \multicolumn{5}{|c|}{$L^{*}$} \\
\hline LDPE $130 \mu \mathrm{m}$ without vacuum & $89.06 \mathrm{aA}$ & 86.28 aA & $75.86 \mathrm{bB}$ & $85.02 \mathrm{aA}$ & $76.96 \mathrm{bB}$ \\
\hline LDPE $130 \mu \mathrm{m}$ with vacuum & $89.06 \mathrm{aA}$ & $86.66 \mathrm{aAB}$ & $80.91 \mathrm{abB}$ & $87.76 \mathrm{aA}$ & $88.29 \mathrm{aA}$ \\
\hline LDPE $200 \mu \mathrm{m}$ without vacuum & $89.06 \mathrm{aA}$ & $85.33 \mathrm{aAB}$ & $80.52 a b B$ & $85.84 \mathrm{aAB}$ & $66.48 \mathrm{cC}$ \\
\hline LDPE 200 um with vacuum & $89.06 \mathrm{aA}$ & $86.14 \mathrm{aA}$ & $85.32 \mathrm{aA}$ & $87.04 \mathrm{aA}$ & $84.53 \mathrm{aA}$ \\
\hline LDPE $300 \mu \mathrm{m}$ without vacuum & $89.06 \mathrm{aA}$ & $86.37 \mathrm{aA}$ & $85.21 \mathrm{aA}$ & $87.42 \mathrm{aA}$ & $86.87 \mathrm{aA}$ \\
\hline LDPE $300 \mu \mathrm{m}$ with vacuum & $89.06 \mathrm{aA}$ & $86.21 \mathrm{aAB}$ & $84.98 \mathrm{aAB}$ & $82.23 \mathrm{aB}$ & $86.53 \mathrm{aAB}$ \\
\hline & \multicolumn{5}{|c|}{$a^{*}$} \\
\hline LDPE $130 \mu \mathrm{m}$ without vacuum & $4.77 \mathrm{aA}$ & $3.32 \mathrm{aB}$ & $2.60 \mathrm{abBC}$ & $2.90 \mathrm{aB}$ & $2.05 \mathrm{bC}$ \\
\hline LDPE $130 \mu \mathrm{m}$ with vacuum & $4.77 \mathrm{aA}$ & $3.26 \mathrm{aB}$ & $2.06 \mathrm{bC}$ & $3.04 \mathrm{aB}$ & $3.01 \mathrm{aB}$ \\
\hline LDPE $200 \mu \mathrm{m}$ without vacuum & $4.77 \mathrm{aA}$ & $2.80 \mathrm{abB}$ & $2.98 \mathrm{aB}$ & $3.08 \mathrm{aB}$ & $2.73 \mathrm{abB}$ \\
\hline LDPE $200 \mu \mathrm{m}$ with vacuum & $4.77 \mathrm{aA}$ & $3.09 \mathrm{abB}$ & $2.86 \mathrm{aB}$ & $2.70 \mathrm{aB}$ & $3.45 \mathrm{aB}$ \\
\hline LDPE $300 \mu \mathrm{m}$ without vacuum & $4.77 \mathrm{aA}$ & $2.31 \mathrm{bC}$ & $2.60 \mathrm{abBC}$ & $3.22 \mathrm{aB}$ & $3.30 \mathrm{aB}$ \\
\hline LDPE $300 \mu \mathrm{m}$ with vacuum & $4.77 \mathrm{aA}$ & $3.11 \mathrm{aBC}$ & $2.88 \mathrm{aBC}$ & $2.75 \mathrm{aC}$ & $3.53 \mathrm{aB}$ \\
\hline & \multicolumn{5}{|c|}{$b^{\star}$} \\
\hline LDPE $130 \mu \mathrm{m}$ without vacuum & $24.97 \mathrm{aA}$ & $21.43 \mathrm{aB}$ & $21.36 \mathrm{aB}$ & $22.49 \mathrm{aAB}$ & $21.23 \mathrm{aB}$ \\
\hline LDPE $130 \mu \mathrm{m}$ with vacuum & $24.97 \mathrm{aA}$ & $21.93 \mathrm{aB}$ & $17.56 \mathrm{bC}$ & $21.51 \mathrm{aB}$ & $22.26 \mathrm{aAB}$ \\
\hline LDPE $200 \mu \mathrm{m}$ without vacuum & $24.97 \mathrm{aA}$ & $21.35 \mathrm{aB}$ & $21.51 \mathrm{aB}$ & $21.26 \mathrm{aB}$ & $21.11 \mathrm{aB}$ \\
\hline LDPE $200 \mu \mathrm{m}$ with vacuum & $24.97 \mathrm{aA}$ & $22.01 \mathrm{aB}$ & $21.22 \mathrm{aB}$ & $21.91 \mathrm{aB}$ & $23.12 \mathrm{aAB}$ \\
\hline LDPE $300 \mu \mathrm{m}$ without vacuum & $24.97 \mathrm{aA}$ & $21.15 \mathrm{aB}$ & $21.03 \mathrm{aB}$ & $22.74 \mathrm{aAB}$ & $23.39 \mathrm{aAB}$ \\
\hline LDPE $300 \mu \mathrm{m}$ with vacuum & $24.97 \mathrm{aA}$ & $21.46 \mathrm{aB}$ & $23.48 \mathrm{aAB}$ & $20.23 \mathrm{aC}$ & $22.02 \mathrm{aABC}$ \\
\hline
\end{tabular}

Means followed by different lowercase and uppercase letters in the same column and row, respectively, differ from each other at $1 \%$ probability by the Tukey test.

In turn, $a^{*}$ values decreased significantly in all treatments until seven days of storage. The values varied significantly for roots in the $300 \mu \mathrm{m}$ nonvacuum LDPE package at seven days of storage. At 14 days, only the $130 \mu \mathrm{m}$ vacuum LDPE package showed significant variation. Moreover, at 28 days, the same occurred for the $130 \mu \mathrm{m}$ nonvacuum LDPE package.
After seven days, only the product subjected to the $200 \mu \mathrm{m}$ LDPE package with and without vacuum did not show significant variation in $a^{*}$ values until the end of storage. These values are responsible for regulating chlorophyll degradation: when $a^{*}$ is positive, the product has a reddish color; when $\mathrm{a}$ * is negative, the product is green (Rinaldi et al., 2017b). 
Similarly, $b^{*}$ values varied significantly during storage except for the product in the $200 \mu \mathrm{m}$ nonvacuum LDPE package after seven days of storage. However, only the product subjected to the $130 \mu \mathrm{m}$ vacuum LDPE package showed a significant reduction in the values of this variable, at 14 days of storage. It is known that $b^{*}$ values represent the yellowing of the vegetable: when $b^{*}$ is positive, the product is yellow; when $b^{*}$ is negative, the product is blue. The values were positive for all days of analysis, corresponding to the characteristic color of the studied cultivar. It is then possible to affirm that there was no significant variation in the color of minimally processed cassava roots subjected to the different treatments during the whole experiment.

\section{Increase in browning, chroma, and hue angle}

The increase in browning determines the browning presented by roots during the storage period (Table 4). The highest value (23.50) occurred for roots in the $200 \mu \mathrm{m}$ nonvacuum LDPE package, on the twenty-eighth day of storage, corresponding to the lowest $L^{*}$ value (66.48) obtained throughout the experiment (Table 3). When the product was packed in the same package but subjected to the vacuum process, it showed a low increase in browning throughout the storage period. The product subjected to the $300 \mu \mathrm{m}$ LDPE package with and without vacuum also showed low increase in browning during the 28 days of storage, proving that this packaging is suitable for maintaining low levels of browning in minimally processed cassava roots stored under refrigeration at $3^{\circ} \mathrm{C}$.

Table 4 - Mean values of increment in browning, chroma and hue angle in minimally processed cassava roots submitted to different treatments.

\begin{tabular}{|c|c|c|c|c|c|}
\hline \multirow{2}{*}{ Packages } & \multicolumn{5}{|c|}{ Days of storage } \\
\hline & 0 & 7 & 14 & 21 & 28 \\
\hline & \multicolumn{5}{|c|}{ Browning } \\
\hline LDPE $130 \mu \mathrm{m}$ without vacuum & $0.00 \mathrm{aC}$ & $5.90 \mathrm{aB}$ & $14.70 \mathrm{aA}$ & $6.95 \mathrm{aB}$ & $13.40 \mathrm{bA}$ \\
\hline LDPE $130 \mu \mathrm{m}$ with vacuum & $0.00 \mathrm{aC}$ & $5.64 \mathrm{aB}$ & $13.88 \mathrm{aA}$ & $6.08 \mathrm{aB}$ & $5.17 \mathrm{cB}$ \\
\hline LDPE $200 \mu \mathrm{m}$ without vacuum & $0.00 \mathrm{aC}$ & $7.84 \mathrm{aB}$ & $10.87 \mathrm{abB}$ & $7.25 \mathrm{aB}$ & $23.50 \mathrm{aA}$ \\
\hline LDPE $200 \mu \mathrm{m}$ with vacuum & $0.00 \mathrm{aB}$ & $5.81 \mathrm{aA}$ & $6.30 \mathrm{bA}$ & $5.30 \mathrm{aA}$ & $7.42 \mathrm{cA}$ \\
\hline LDPE $300 \mu \mathrm{m}$ without vacuum & $0.00 \mathrm{aB}$ & $6.80 \mathrm{aA}$ & $7.32 \mathrm{bA}$ & $6.21 \mathrm{aA}$ & $6.76 \mathrm{cA}$ \\
\hline LDPE $300 \mu \mathrm{m}$ with vacuum & $0.00 \mathrm{aB}$ & $6.17 \mathrm{aA}$ & $7.16 \mathrm{bA}$ & $8.69 \mathrm{aA}$ & $6.27 \mathrm{cA}$ \\
\hline \multicolumn{6}{|c|}{ Chroma } \\
\hline LDPE $130 \mu \mathrm{m}$ without vacuum & $25.44 \mathrm{aA}$ & $21.71 \mathrm{aB}$ & $21.53 \mathrm{aB}$ & $22.69 \mathrm{aAB}$ & $21.47 \mathrm{aB}$ \\
\hline LDPE $130 \mu \mathrm{m}$ with vacuum & $25.44 \mathrm{aA}$ & $22.19 \mathrm{aB}$ & $17.70 \mathrm{bC}$ & $21.74 \mathrm{aB}$ & $22.88 \mathrm{aAB}$ \\
\hline LDPE $200 \mu \mathrm{m}$ without vacuum & $25.44 \mathrm{aA}$ & $21.54 \mathrm{aB}$ & $22.20 \mathrm{aB}$ & $21.50 \mathrm{aB}$ & $21.36 \mathrm{aB}$ \\
\hline LDPE $200 \mu \mathrm{m}$ with vacuum & $25.44 \mathrm{aA}$ & $22.24 \mathrm{aB}$ & $21.43 \mathrm{aB}$ & $22.08 \mathrm{aB}$ & $23.63 \mathrm{aAB}$ \\
\hline LDPE $300 \mu \mathrm{m}$ without vacuum & $25.44 \mathrm{aA}$ & $21.30 \mathrm{aB}$ & $21.21 \mathrm{aB}$ & $22.99 \mathrm{aAB}$ & $23.98 \mathrm{aAB}$ \\
\hline LDPE $300 \mu \mathrm{m}$ with vacuum & $25.44 \mathrm{aA}$ & $21.70 \mathrm{aBC}$ & $23.67 \mathrm{aAB}$ & $19.86 \mathrm{aC}$ & $22.73 \mathrm{aABC}$ \\
\hline \multicolumn{6}{|c|}{ Hue angle } \\
\hline LDPE $130 \mu \mathrm{m}$ without vacuum & $79.24 \mathrm{aA}$ & $81.39 \mathrm{aA}$ & $83.16 \mathrm{aA}$ & $82.58 \mathrm{aA}$ & $84.17 \mathrm{aA}$ \\
\hline LDPE $130 \mu \mathrm{m}$ with vacuum & $79.24 \mathrm{aA}$ & $81.60 \mathrm{aA}$ & $83.41 \mathrm{aA}$ & $82.12 \mathrm{aA}$ & $82.93 \mathrm{aA}$ \\
\hline LDPE $200 \mu \mathrm{m}$ without vacuum & $79.24 \mathrm{aA}$ & $82.64 \mathrm{aA}$ & $82.24 \mathrm{aA}$ & $81.80 \mathrm{aA}$ & $82.77 \mathrm{aA}$ \\
\hline LDPE $200 \mu \mathrm{m}$ with vacuum & $79.24 \mathrm{aA}$ & $81.89 \mathrm{aA}$ & $82.45 \mathrm{aA}$ & $83.14 \mathrm{aA}$ & $81.63 \mathrm{aA}$ \\
\hline LDPE $300 \mu \mathrm{m}$ without vacuum & $79.24 \mathrm{aA}$ & $83.79 \mathrm{aA}$ & $83.08 \mathrm{aA}$ & $82.09 \mathrm{aA}$ & $82.21 \mathrm{aA}$ \\
\hline LDPE $300 \mu \mathrm{m}$ with vacuum & $79.24 \mathrm{aA}$ & $81.93 \mathrm{aA}$ & $82.63 \mathrm{aA}$ & $78.07 \mathrm{aA}$ & $81.38 \mathrm{aA}$ \\
\hline
\end{tabular}

Means followed by different lowercase and uppercase letters in the same column and row, respectively, differ from each other at $1 \%$ probability by the Tukey test.

The increase in browning is measured to assess the browning of the product during storage. In general, for plant products, when values regarding this increase are higher than 10 , the degree of browning is considered high (Rinaldi et al., 2017c). In the present study, the values ranged from 0 to 23.50 , and the products packed in $200 \mu \mathrm{m}$ vacuum LDPE and $300 \mu \mathrm{m}$ LDPE with and without vacuum showed values below the maximum limit during the 28 days of storage. Hence, these treatments are considered effective in the browning control of minimally processed cassava roots. As for the variability obtained during the experiment, a factor that can interfere with the calorimetry analysis of cassava is the samples being destructive, that is, a new sample is used for each time of evaluation. The cassava must be removed from the package for analysis, and repackaging is not advisable due to the modification of the atmosphere around the product (Henrique et al., 2015).

Chroma values ranged from 17.70 to 25.44 , corresponding to faint colors, of low intensity, tending to white (Table 4). Chroma values define color intensity, where values close to zero correspond to neutral colors, and values close to sixty account for stronger colors (Tunick, 2000). Chroma is a variable related to the degree of purity of the color, which delimits the saturation level by the black or white scale that contains it (Reis et al., 2017). 
The chroma values obtained during the storage period did not differ significantly between packages, except for the product subjected to the $130 \mu \mathrm{m}$ with vacuum LDPE package, at 14 days of storage, with the lowest chroma (17.70) of the whole experiment (Table 4). It is not possible to state that the packages had any effect on the chroma values of minimally processed cassava roots during the 28 days of storage.

Moreover, hue angle values also did not vary significantly during the 28 days of storage of minimally processed cassava roots conditioned in the different packaging systems. The hue angle (h) of roots in the different treatments ranged between 78.07 and 84.17 throughout the storage period, corresponding to the yellow color (Table 4). The hue angle characterizes different color shades every $90^{\circ}$, as follows: $0^{\circ}$ red, $90^{\circ}$ yellow, $180^{\circ}$ green, and $270^{\circ}$ blue (Silva et al., 2015).

\section{Moisture, dry matter, and cooking time}

Moisture values ranged from $56.97 \%$ to $63.06 \%$, with an overall mean of $60.94 \%$ during the 28 days of storage. The moisture content of roots subjected to the $130 \mu \mathrm{m}$ vacuum LDPE package and the $300 \mu \mathrm{m}$ LDPE package in the two atmosphere conditions did not vary significantly throughout the storage period. The other treatments showed oscillation in moisture values during storage (Table 5). In general, the moisture values of minimally processed cassava roots agree with the data obtained by Rinaldi et al. (2015a, b) and Rinaldi et al. (2017a).

Table 5 - Mean values of moisture, dry matter and cooking time in minimally processed cassava roots submitted to different treatments.

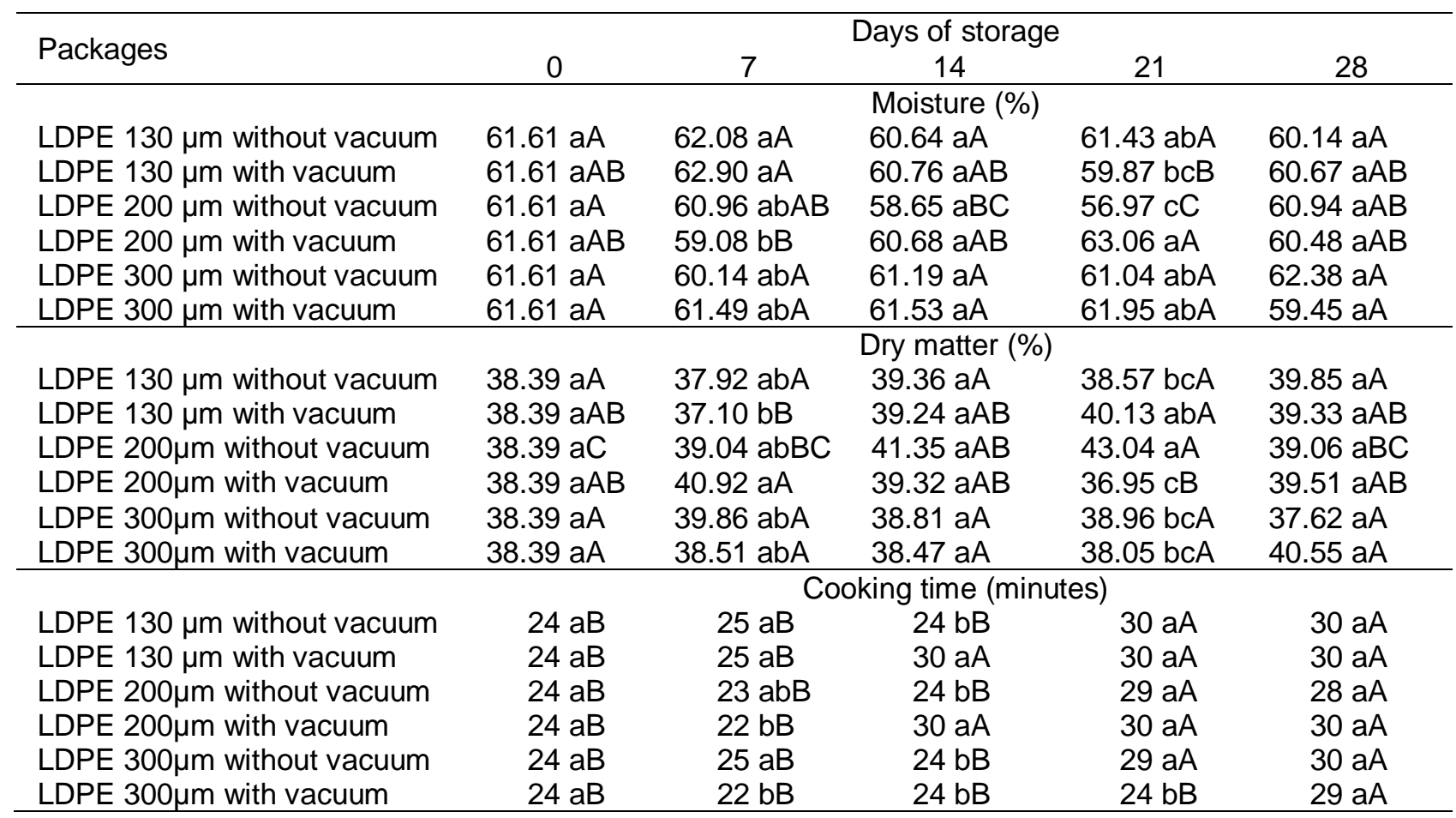

Means followed by different lowercase and uppercase letters in the same column and row, respectively, differ from each other at $1 \%$ probability by the Tukey test.

The moisture results obtained in this work also agree with those presented by TACO (Unicamp, 2011) in raw cassava roots (61.80\%). Bezerra et al. (2002) highlight the importance of maintaining the moisture of cassava roots during storage, since a decrease implies favoring enzymatic reactions that culminate in vascular discoloration. According to the same authors, increased moisture values due to packaging, inadequate centrifugation, and other storage problems can facilitate the multiplication of microorganisms present in the product, decreasing its shelf life.

Dry matter values ranged from 36.95 to 43.04 , with an overall mean of 39.06 . The roots subjected to the $200 \mu \mathrm{m}$ vacuum LDPE package showed the highest dry matter content, while the $200 \mu \mathrm{m}$ nonvacuum LDPE package accounted for the lowest value (Table
5). The dry matter percentage of roots packed in the $130 \mu \mathrm{m}$ nonvacuum LDPE package and in the $300 \mu \mathrm{m}$ LDPE package with and without vacuum did not vary significantly during the 28 days of storage, proving that these packages were more stable in maintaining the dry matter content of minimally processed cassava roots. Root dry matter values are highly related to starch content, depending on the variety, crop location, age, and harvesting time (Fukuda et al., 2006).

The cooking time of cassava roots ranged between 22 and 30 minutes. It is noteworthy that 30 minutes is the maximum acceptable time for commercialization of cassava roots for culinary purposes (Fukuda et al., 2002; Vieira et al., 2018) (Table 5). The lower the cooking time, the better the mass quality (Talma et al., 2013). In addition, low cooking time leads 
to energy and time savings, which is desired by the final consumer (Moreto \& Neubert, 2014). Rapid cooking of cassava roots is also associated with soft texture and crispness of fried cassava (Schallenberger et al., 2016).

The cooking time of roots subjected to the $130 \mu \mathrm{m}$ vacuum LDPE and 200 $\mu \mathrm{m}$ vacuum LDPE packages increased significantly from 14 days of storage, these values being maintained until the end of the experiment. For the other treatments, with the exception of the $300 \mu \mathrm{m}$ vacuum LDPE package, the cooking time increased significantly after 21 days of storage. However, this variable also increased at 28 days for roots in the $300 \mu \mathrm{m}$ vacuum LDPE package, reaching 29 minutes. Furthermore, Bezerra et al. (2002) observed significant differences in root cooking time as a function of storage periods, with a reduced amplitude, ranging from 24.85 to 27.70 minutes and increasing during storage. Freire et al. (2014) also observed increased root cooking time for cassava cultivar Mossoró minimally processed into different formats ("minitolete" and "rubiene").

The increase in root cooking time in the described periods is probably due to the characteristics of the raw material. It is not possible to affirm that the thickness of the package and the vacuum process had a significant influence on this variable. Regarding cassava roots, samples from the same root or cultivar may differ in cooking quality. A sample may show proper cooking as opposite to the other, even with the same characteristics of cultivation, harvest, and other factors such as climate, soil, postharvest handling, and storage management.

The cooking time considered adequate for cassava roots is 11 to 20 minutes (Pereira et al., 1985). Cereda et al. (1990) reported a cooking time of 13.5 minutes for cultivar 279 . The cooking time and culinary parameters of cassava roots may vary between roots of the same plant, between plants of the same variety, between different genetic materials, and depending on the physiological status of plants, soil and climate conditions, and harvesting times (Fialho et al., 2009). Plants harvested earlier have shorter cooking time (Oliveira \& Moraes, 2009). Cooking time is thus the main feature related to culinary quality. Teixeira et al. (2017) state that cassava consumers are demanding about root cooking time, which must be as short as possible to be considered of good quality. These authors obtained a cooking time of 14 minutes for the same variety of this study.

However, since the cooking time was less than 30 minutes for all treatments, it is possible to affirm that all were efficient in maintaining the culinary qualities of cassava roots.

There was no presence of mesophilic aerobes, psychrotrophic aerobes, molds and yeasts, total and thermotolerant coliforms after minimal processing of roots (day zero), proving that the raw material was in good microbiological conditions and that minimal processing was performed adequately (Table 6).
The total count of mesophilic aerobes ranged from < 10 (est.) in the raw material to $2.2 \times 10^{5} \mathrm{CFU} \mathrm{g}^{-1}$ in the treatment of $130 \mu \mathrm{m}$ nonvacuum LDPE at 28 days of storage. The lowest counts of mesophilic aerobes during storage were obtained for the treatments $200 \mu m$ vacuum LDPE and $300 \mu m$ vacuum LDPE. Therefore, when allied to the vacuum process, these packages are effective in reducing mesophilic aerobes in minimally processed cassava roots. In these treatments, the count reached a maximum of $10^{3}$ up to 28 days of storage. The presence of a large number of mesophilic microorganisms in food may be indicative of product maintenance under improper conditions (Franco \& Landgraf, 2005). When allied to the vacuum process, the packages with greater thickness in the present study showed a lower count of these microorganisms. Although mesophilic aerobes do not have a maximum tolerance established in Brazil, the APHA (American Public Health Association) establishes the limit of $1.4 \times 10^{3} \mathrm{CFU} \mathrm{g}^{-1}$ (Doores et al., 2013) for safety in the commercialization and consumption of the product.

The total psychrotrophic count ranged from $<10$ (est.) in the roots immediately after processing to $1.5 \times 10^{5} \mathrm{CFU} \mathrm{g}^{-1}$ in the treatment of $130 \mu \mathrm{m}$ nonvacuum LDPE at 21 days of storage (Table 6). In Brazilian legislation, there is no standard for these microorganisms in foods, but high amounts $\left(>10^{5} \mathrm{CFU} \mathrm{g}^{-1}\right.$ ) are completely undesirable. At these levels, food may be inadequate for consumption, with actual or potential loss of sensory qualities, impaired appearance, and presence of pathogenic and/or deteriorating microorganisms (Caruso \& Camargo, 1984). In the present study, only the roots subjected to $130 \mu \mathrm{m}$ LDPE treatments with and without vacuum showed counts reaching $10^{5}$, from 21 days of storage. The roots subjected to the other treatments did not reach the limit for the commercialization of products, being in acceptable conditions regarding these microorganisms until the end of storage. Positively, the lowest values of psychrotrophic aerobes were observed in the 200 and $300 \mu \mathrm{m}$ vacuum LDPE treatments, again proving the efficiency of these treatments in the microbial control of minimally processed cassava roots.

For molds and yeasts, the treatments showed a count ranging from $<10$ (est.) to $8.5 \times 10^{4} \mathrm{CFU} \mathrm{g}^{-1}$ during storage, with higher values in $130 \mu \mathrm{m}$ LDPE treatments with and without vacuum. Once again, products subjected to the $200 \mu \mathrm{m}$ vacuum LDPE and $300 \mu \mathrm{m}$ vacuum LDPE packages showed less microbial contamination. Resolution RDC No. 12 of January 2, 2001 (Brasil, 2001) sets a limit value only for Salmonella and thermotolerant coliforms in refrigerated and frozen vegetables. However, in general, the lower the amount of mold and yeast in a food, the longer its shelf life and consumer safety.

The thermotolerant coliform count was also low, with maximum value of $<3 \mathrm{MPN} \mathrm{g}^{-1}$, meeting the requirements of the legislation (Brasil, 2001). Resolution RDC N ${ }^{\circ} .12$ of January 2, 2001 regulates microbi- 
ological standards for fresh and prepared vegetables, defining as a limit the coliform content of $10^{2} \mathrm{MPN} \mathrm{g}^{-1}$ at $45^{\circ} \mathrm{C}$ (Passos et al., 2017). Thus, minimally processed cassava roots were adequate regarding thermotolerant coliforms in all treatments.

Alves et al. (2005) report that minimally processed cassava roots stored in a styrofoam tray wrapped in polyvinyl chloride film (uninformed thickness) showed physiological, microbiological, and sen- sory deterioration from the 7th day of storage. In contrast, those stored in a vacuum-sealed multilayer package showed the same deterioration only on the 24th day of storage. The proliferation of microorganisms during storage is evident in foods with $\mathrm{pH}$ higher than 4.5 (Nutrição e Saúde, 2018). The $\mathrm{pH}$ of cassava roots is higher than this value, justifying the results obtained in the count of the microorganisms evaluated in the experiment.

Table 6 - Mean values of total counts of mesophilic aerobes, psychrotrophic aerobes, molds and yeasts, total and thermotolerant coliforms in minimally processed cassava roots submitted to different treatments.

\begin{tabular}{|c|c|c|c|c|c|}
\hline \multirow{2}{*}{ Packages } & \multicolumn{5}{|c|}{ Days of storage } \\
\hline & 0 & 07 & 14 & 21 & 28 \\
\hline & \multicolumn{5}{|c|}{ Total counts of mesophilic aerobes $\left({ }^{*} \mathrm{CFU} \mathrm{g}^{-1}\right)$} \\
\hline LDPE $130 \mu \mathrm{m}$ without vacuum & $<10$ est $^{\star}$ & $3.3 \times 10^{2}$ & $1.5 \times 10^{4}$ & $8.0 \times 10^{4}$ & $2.2 \times 10^{5}$ \\
\hline LDPE $130 \mu \mathrm{m}$ with vacuum & $<10$ est & $1.5 \times 10^{2}$ est & $5.9 \times 10^{3}$ & $6.6 \times 10^{4}$ & $1.7 \times 10^{5}$ \\
\hline LDPE $200 \mu \mathrm{m}$ without vacuum & $<10$ est & $3.0 \times 10^{2}$ & $1.7 \times 10^{3}$ & $5.7 \times 10^{4}$ & $3.1 \times 10^{5}$ \\
\hline LDPE $200 \mu \mathrm{m}$ with vacuum & $<10$ est & $1.2 \times 10^{2}$ est & $2.9 \times 10^{2}$ & $4.6 \times 10^{3}$ & $1.7 \times 10^{3}$ \\
\hline LDPE $300 \mu \mathrm{m}$ without vacuum & $<10$ est & $3.3 \times 10^{2}$ & $7.6 \times 10^{4}$ & $7.3 \times 10^{3}$ & $1.0 \times 10^{4}$ \\
\hline \multirow[t]{2}{*}{ LDPE $300 \mu \mathrm{m}$ with vacuum } & $<10$ est & $2.6 \times 10^{2}$ & $1.6 \times 10^{2}$ est & $1.3 \times 10^{3}$ & $3.2 \times 10^{3}$ \\
\hline & \multicolumn{5}{|c|}{ Total counts of psychrotrophic aerobes (CFU g ${ }^{-1}$ ) } \\
\hline LDPE $130 \mu \mathrm{m}$ without vacuum & $<10$ est & $4.8 \times 10^{3}$ & $4.9 \times 10^{4}$ & $1.5 \times 10^{5}$ & $6.9 \times 10^{5}$ \\
\hline LDPE $130 \mu \mathrm{m}$ with vacuum & $<10$ est & $8.6 \times 10^{2}$ & $8.5 \times 10^{3}$ & $1.3 \times 10^{5}$ & $6.8 \times 10^{5}$ \\
\hline LDPE $200 \mu \mathrm{m}$ without vacuum & $<10$ est & $3.3 \times 10^{2}$ & $5.9 \times 10^{3}$ & $8.1 \times 10^{4}$ & $5.5 \times 10^{3}$ \\
\hline LDPE $200 \mu \mathrm{m}$ with vacuum & $<10$ est & $<10$ est & $1.4 \times 10^{2}$ est & $4.5 \times 10^{3}$ & $4.3 \times 10^{3}$ \\
\hline LDPE $300 \mu \mathrm{m}$ without vacuum & $<10$ est & $4.5 \times 10^{2}$ & $3.4 \times 10^{2}$ & $1.1 \times 10^{4}$ & $3.1 \times 10^{4}$ \\
\hline \multirow[t]{2}{*}{ LDPE $300 \mu \mathrm{m}$ with vacuum } & $<10$ est & $<10$ est & $1.3 \times 10^{2} \mathrm{est}$ & $3.6 \times 10^{2}$ & $2.8 \times 10^{3}$ \\
\hline & \multicolumn{5}{|c|}{ Total counts of molds and yeasts (CFU g ${ }^{-1}$ ) } \\
\hline LDPE $130 \mu \mathrm{m}$ without vacuum & $<10$ est & $<10$ est & $8.6 \times 10^{3}$ & $9.7 \times 10^{2}$ & $8.5 \times 10^{4}$ \\
\hline LDPE $130 \mu \mathrm{m}$ with vacuum & $<10$ est & $<10$ est & $1.4 \times 10^{3}$ & $4.0 \times 10^{2}$ & $7.6 \times 10^{4}$ \\
\hline LDPE $200 \mu \mathrm{m}$ without vacuum & $<10$ est & $<10$ est & $1.8 \times 10^{3}$ & $3.8 \times 10^{2}$ & $8.5 \times 10^{2}$ \\
\hline LDPE $200 \mu \mathrm{m}$ with vacuum & $<10$ est & $<10$ est & $<10$ est & $2.6 \times 10^{2}$ & $5.0 \times 10^{2}$ \\
\hline LDPE $300 \mu \mathrm{m}$ without vacuum & $<10$ est & $<10$ est & $7.2 \times 10^{2}$ & $2.2 \times 10^{2}$ & $1.3 \times 10^{3}$ \\
\hline \multirow[t]{2}{*}{ LDPE $300 \mu \mathrm{m}$ with vacuum } & $<10$ est & $<10$ est & $<10$ est & $1.9 \times 10^{2}$ & $4.6 \times 10^{2}$ \\
\hline & \multicolumn{5}{|c|}{ Total coliforms $\left({ }^{*} \mathrm{MPN} \mathrm{g}^{-1}\right)$} \\
\hline LDPE $130 \mu \mathrm{m}$ without vacuum & $<3$ & $1.1 \times 10^{2}$ & $1.1 \times 10^{2}$ & $6.4 \times 10^{4}$ & $1.1 \times 10^{5}$ \\
\hline LDPE $130 \mu \mathrm{m}$ with vacuum & $<3$ & $1.1 \times 10^{2}$ & $1.1 \times 10^{2}$ & $3.6 \times 10^{1}$ & $1.1 \times 10^{5}$ \\
\hline LDPE $200 \mu \mathrm{m}$ without vacuum & $<3$ & $<3$ & $1.1 \times 10^{2}$ & $2.1 \times 10^{3}$ & $2.4 \times 10^{4}$ \\
\hline LDPE $200 \mu \mathrm{m}$ with vacuum & $<3$ & $<3$ & $1.1 \times 10^{2}$ & $1.1 \times 10^{5}$ & $1.1 \times 10^{5}$ \\
\hline LDPE $300 \mu \mathrm{m}$ without vacuum & $<3$ & $2.3 \times 10^{3}$ & $3.0 \times 10^{1}$ & $4.3 \times 10^{3}$ & $1.1 \times 10^{5}$ \\
\hline \multirow[t]{2}{*}{ LDPE $300 \mu \mathrm{m}$ with vacuum } & $<3$ & $<3$ & $<3$ & $<3$ & $1.1 \times 10^{5}$ \\
\hline & \multicolumn{5}{|c|}{ Thermotolerant coliforms $\left(\mathrm{MPN} \mathrm{g}^{-1}\right)$} \\
\hline LDPE $130 \mu \mathrm{m}$ without vacuum & $<3$ & $<3$ & $<3$ & $<3$ & $<3$ \\
\hline LDPE $130 \mu \mathrm{m}$ with vacuum & $<3$ & $<3$ & $<3$ & $<3$ & $<3$ \\
\hline LDPE $200 \mu \mathrm{m}$ without vacuum & $<3$ & $<3$ & $<3$ & $<3$ & $<3$ \\
\hline LDPE $200 \mu \mathrm{m}$ with vacuum & $<3$ & $<3$ & $<3$ & $<3$ & $<3$ \\
\hline LDPE $300 \mu \mathrm{m}$ without vacuum & $<3$ & $<3$ & $<3$ & $<3$ & $<3$ \\
\hline LDPE $300 \mu \mathrm{m}$ with vacuum & $<3$ & $<3$ & $<3$ & $<3$ & $<3$ \\
\hline
\end{tabular}

${ }^{*} \mathrm{CFU}$ : Colony forming units; ${ }^{*}$ est: estimated; ${ }^{*} \mathrm{MPN}$ : Most probable number. 


\section{Conclusions}

Minimally processed cassava roots packed in LDPE packages with greater thickness $(200 \mu \mathrm{m}$ and $300 \mu \mathrm{m})$ show greater stability in physicochemical and microbiological components.

When using the $200 \mu \mathrm{m}$ vacuum LDPE package and the $300 \mu \mathrm{m}$ LDPE package in the two atmosphere conditions, with storage at a temperature of $3 \stackrel{\circ}{\mathrm{C}}$ and $90 \%$ relative humidity, the shelf life of minimally processed cassava roots is 14 days. For the other treatments, the recommended storage period is seven days.

\section{Acknowledgements}

The authors thank the Brazilian Agricultural Research Corporation (Embrapa) and the Banco do Brasil Foundation (FBB) for financial support.

\section{References}

Alves A, Cansian, RL, Stuart, G, Valduga, E (2005) Alterações na qualidade de raízes de mandioca (Manihot esculenta Crantz) minimamente processada. Ciência e Agrotecnologia 29(2):330-337.

Andrade AU, Sanches AG, Piacentini LC, Cordeiro CAM (2016) Tratamento pós-colheita na extensão da vida útil de mandioca de mesa polpa branca e amarela minimamente processada e frigoconservada. Acta Iguazu 5(4):1-14.

Bezerra VL, Pereira RGFA, Carvalho VD, Vilela ER (2002) Raízes de mandioca minimamente processadas: efeito do branqueamento na qualidade e na conservação. Ciência e Agrotecnologia 26(3):564-575.

Brasil (2001) RDC no 12, de 02 de janeiro de 2001. Dispõe Sobre o Regulamento Técnico Sobre os Padrões Microbiológicos Para Alimentos. Brasília.

Butarelo SS, Beleia A, Fonseca ICB, Ito KC (2004) Hidratação de tecidos de raízes de mandioca (Manihot esculenta Crantz.) e gelatinização do amido durante a cocção. Ciência e Tecnologia de Alimentos 24(3):311315.

Caruso JGB, Camargo R (1984) Microbiologia de alimentos. In: Camargo R (ed) Tecnologia dos produtos agropecuários-alimentos, Nobel. p.35-49.

Carvalho CRL, Mantovani DMB, Carvalho PRN, Moraes RMM (1990) Análises químicas de alimentos. ITAL. p.121.

Castricini A, Rodrigues MGV, Jesus AM, Serpa MFP (2014) Caracterização de raízes de genótipos de mandioca produzidos no Semiárido de Minas Gerais. Revista Raízes e Amidos Tropicais 10(1):23-37. doi: 10.17766/1808-981X.
Cavalini FC, Jacomino AP, Lochoski M A, Kluge RA, Ortega EMM (2006) Maturity indexes for "kumagai" and "paluma" guavas. Revista Brasileira de Fruticultura 28(2):176-179.

Cereda MP, Sarmento SBS, Wosiacki G, Abbud NS (1990) A mandioca (Manihot esculenta, C.) cultivar IAPAR-19 Pioneira 3- Características culinárias. Arquivos de Biologia e Tecnologia 33(3):511-525.

Cenci AS (2011) Processamento mínimo de frutas e hortaliças: tecnologia, qualidade e sistemas de embalagem. Embrapa Agroindústria de Alimentos. 144p.

Chitarra, M. I. F.; Chitarra, A. B (2005) Pós colheita de frutas e hortaliças: fisiologia e manuseio. UFLA. 785p.

Doores S, Slafinger Y, Tortorello, M (2013) Compendium of methods for the microbiological examination of foods. DC: American Public Health Association. 185p.

Fernandes AM, Soratto RP, Evangelista RM, Nardin I (2010) Qualidade físico-química e de fritura de tubérculos de cultivares de batata na safra de inverno. Horticultura Brasileira 28(3):299-304.

Fernandes LS, Corrêa PC, Junqueira MS, Finger FL, Cecon PR (2016) Influence of the type of packaging on textural properties of minimally processed yellow Peruvian roots. Revista Ceres 63(3):291-296.

Fialho JF, Vieira EA, Silva MS, Paula-Moraes SV, Fukuda WMG, Santos Filho MOS, SILVA KN (2009) Desempenho de variedades de mandioca de mesa no Distrito Federal. Revista Brasileira de Agrociência 15(1-4):31-35.

Franco BDGM, Landgraf M (2005) Microbiologia de Alimentos. Atheneu. 182p.

Freire CS, Simões NA, Vieira MRS, Júnior APB, Costa FB (2014) Qualidade de raízes de mandioca de mesa minimamente processada nos formatos minitolete e rubiene. Revista Caatinga 27(4):95-102.

Freitas RVS, Souza PA, Coelho EL, Souza FX, Beserra HNBR (2017) Storage of mombin fruits coated with cassava starch and pvc film. Revista Caatinga 30(1):244-249.

21252017v30n127rc

Fukuda WMG, Silva SO, Iglesias C (2002) Cassava breeding. Crop Breeding and Applied Biotechnology 2(4): 617-638.

Fukuda WMG, Fukuda C, Vasconcelos O, Folgaça JL, Neves HP, Carneiro GT (2006) Variedades de mandioca recomendadas para o Estado da Bahia. Bahia Agrícola 7(3):27-30. 
Henrique CM, Prati P, Sarmento SBS (2015) Alterações de cor em raízes de mandioca minimamente processadas e embaladas a vácuo. Revista Iberoamericana de Tecnología Postcosecha 16(1):129-135.

Hunterlab (2008) Insight on color: CIE $L^{*} a^{*} b^{*}$ color scale. Reston, VA, USA.

Lima RAZ, Tomé LM, Abreu CMP (2014) Embalagem a vácuo: efeito no escurecimento e endurecimento do feijão durante 0 armazenamento. Ciência Rural 44(9):1664-1670. doi: 10.1590/0103-8478cr20120832

Moreto AL, Neubert EO (2014) Avaliação de produtividade e cozimento de cultivares de mandioca de mesa (aipim) em diferentes épocas de colheita. Revista Agropecuária Catarinense 27(1):59-65.

Moreto VB, Aparecido LEO, Rolim GS, Moraes JRSC (2018) Agrometeorological models for estimating sweet cassava yield. Pesquisa Agropecuária Tropical 48(1):43-51.

$40632018 v 4850451$.

Nutrição e Saúde. Apostila de tecnologia de alimentos princípios. Disponível em: http://www.ebah.com.br/tecnologia-dos-alimentos-pdfa46754.html (Acesso em 23 de nov de 2018).

Oliveira MA, Moraes PSB (2009) Características físicoquímicas, cozimento e produtividade de mandioca cultivar IAC576-70 em diferentes épocas de colheita. Ciência e Agrotecnologia 33(3):837-843. doi: 10.1590/S1413-70542009000300024.

Passos LP, Miranda ALS, Marques DRP, Oliveira IRN (2017) Aspectos microbiológicos de cenouras minimamente processadas e armazenadas em diferentes embalagens sob-refrigeração. The Journal of Engineering and Exact Sciences 03(6):0829-0834. doi: 10.18540/jcecvl3iss6pp0829-0834.

Pereira AS, Lorenzi JO, Valle TL (1985) Avaliação do tempo de cozimento e padrão de massa cozida em mandioca de mesa. Revista Brasileira de Mandioca $4(1): 27-32$.

Ramos PAS, Sediyama T, Viana AES, Pereira DM, Finger FL (2013) Efeito de inibidores da peroxidase sobre a conservação de raízes de mandioca in natura. Brazilian Journal of Food Technology 6(2):116-124. doi.org/10.1590/S1981-67232013005000018.

Reis DS, Figueiredo Neto A, Ferraz AV, Freitas ST (2017) Produção e estabilidade de conservação de farinha de acerola desidratada em diferentes temperaturas. Brazilian Journal Food Technology 20( e2015083). doi.org/10.1590/1981-6723.8315.

Ricciardi A (2008) Embalagens de cárneos. Revista Nacional da Carne 376:39-40.
Rinaldi MM, Vieira EA, Fialho JF (2015a) Conservação pós-colheita de diferentes cultivares de mandioca submetidas ao processamento mínimo e congelamento. Científica 43(4):287-301. doi.org/10.15361/1984-5529.2015v43n4p287-301.

Rinaldi MM, Vieira EA, Fialho JF, Malaquias JV (2015b) Efeito de diferentes formas de congelamento sobre raízes de mandioca de mesa. Brazilian Journal of Food Technology 18(2):93-101. doi.org/10.1590/1981-6723.3414.

Rinaldi MM, Vieira EA, Fialho JF, Malaquias JV (2017a) Shelf life of minimally processed cassava roots submitted to different conservation methods. Científica 45(1):9-17.

5529.2017v45n1p9-17. doi.org/10.15361/1984-

Rinaldi MM, Fialho JF, Vieira EA, Oliveira TAR, Assis SFO (2017b) Utilização de ácido cítrico para a conservação pós-colheita de raízes de mandioca. Brazilian Journal Food Technology 20(e2017072). doi.org/10.1590/1981-6723.07217.

Rinaldi MM, Costa AM, Faleiro FG, Junqueira NTV (2017c) Conservação pós-colheita de frutos de Passiflora setacea DC. submetidos a diferentes sanitizantes e temperaturas de armazenamento. Brazilian Journal Food Technology 20(e2016046). doi.org/10.1590/1981-6723.4616.

Santiago AD, Cavalcante MHB, Braz GBP, Procópio SO (2018) Efficacy and selectivity of herbicides applied in cassava pre-emergence. Revista Caatinga 31(3):640-650.

21252018v31n312rc. doi.org/10.1590/1983-

Schallenberger E, Rebelo JA, Cantú RR, Morales RGF, Neubert EO, Moreto AL (2016) Novas cultivares de aipim: SCS256 Seleto, SCS257 Estação EEI, SCS 258 Peticinho e SCS259 Diamante. Agropecuária Catarinense 29(1):58-62.

Silva DFP, Siqueira DL, Pereira CS, Salomão LCC, Struiving TB (2015) Caracterização de frutos de 15 cultivares de mangueira na Zona da Mata mineira. Ceres 56(6):783-789.

Silva FAZ (2015) ASSISTAT, Universidade Federal de Campina Grande. INPI 0004051-2. Versão 7.7 Beta (pt), Campina Grande - PB - Brasil, Disponível em: <http://www.assistat.com>. Acesso out., 2017.

Silva N, Junqueira VCA, Silveira NFA, Taniwaki MH, Santos RFS, Gomes RAR (2010) Manual de métodos de análise microbiológica de alimentos e água. Livraria Varela. 624p.

Smanioto TF, Pirolo NJ, Simionato EMRS, Arruda MD (2009) Qualidade microbiológica de frutas e hortaliças minimamente processadas. Revista Instituto Adolfo Lutz 68(1):150-154. 
Talma SV, Almeida SB, Lima RMP, Vieira HD, Bebert PA (2013) Tempo de cozimento e textura de raízes de mandioca. Brazilian Journal of Food Technology 16(2):133-138. doi: 10.1590/S1981-

67232013005000016.

Teixeira PRG, Viana AES, Cardoso AD, Moreira GLP Matsumoto SN, Ramos PAC (2017) Physical-chemical characteristics of sweet cassava varieties. Agrária Revista Brasileira de Ciências Agrárias 12(2):158-165. doi:10.5039/agraria.v12i2a5433.

Tunick MH (2000) Rheology of dairy foods that gel, stretch, and fracture. Journal Dairy Science, Champaign, 83(8):1892-1989. doi: 10.3168/jds.S00220302(00)75062-4.

Universidade Estadual de Campinas - Unicamp. Tabela Brasileira de Composição de Alimentos TACO. versão 2. Unicamp; NEPA, 2011. 113 p. Disponível em: <http://www.unicamp.br/nepa/taco/contar/taco_versao 2.pdf>. Acesso em: 20 de nov. 2018.
Vieira EA, Fialho JF, Julio I, Carvalho LJCB, Corte JLD, Rinaldi MM, Oliveira CM, Fernandes FD, Anjos JRN (2018) Sweet cassava cultivars with yellow or cream root pulp developed by participatory breeding. Crop Breeding and Applied Biotechnology 18:450-454. doi.org/10.1590/1984- 70332018v18n4c67.

Vieites RL, Daiuto ER, Carvalho LR, Garcia MR, Lozano MG, Watanabe LM (2012) Mandioca minimamente processada submetida à radiação gama. Semina: Ciências Agrárias 33(1):271-282. doi: 10.5433/1679-0359.2012v33n1p271. 